\title{
The Investigation Process of Prospective Children in Criminal Action
}

\author{
Ari Yudistira ${ }^{*}$ and Widayati ${ }^{* *}$ \\ ${ }^{*}$ Student of Master of Law, Faculty of Law, Universitas Islam Sultan Agung Semarang \\ and Police Staff of Narcotics Investigator of Cirebon, E-mail: aryyudistira29@gmail.com \\ ${ }^{* *}$ Lecturer of Master of Law, Universitas Islam Sultan Agung Semarang
}

\begin{abstract}
The objectives of this research are: To identify and analyze the process of investigating child suspects in drug crimes. To find out and analyze the obstacles in the process of investigating child suspects in drug crimes and their solutions. This study uses a sociological juridical approach, with descriptive analytical research specifications. The data used in this research is secondary data obtained through library research and primary data. The results of this study on process of investigating child suspects in drug crime includes: a) Detention period for children is only valid for a maximum of 7 (seven) days and can be extended by the public prosecutor for a maximum of 8 (eight) days. b) Investigations against perpetrators of child crime are carried out by child investigators. c) In conducting an investigation, the investigator is obliged to ask for consideration from the Correctional Center (BAPAS). Barriers: a) The duration of research from the Correctional Institution (BAPAS). b) The unavailability of special investigators for children due to limited Human Resources (HR). The solution: a) To increase the ability of investigators to carry out investigations so that they are able to resolve cases during the period of time the child is detained according to the rules, namely 7 (days) of work and can extend detention by 8 (eight) working days b) Increasing the working relationship with BAPAS so that research and research results on children can be completed immediately. So that the results of the research can be completed immediately before the investigator hands over the child and evidence to the Public Prosecutor (JPU).
\end{abstract}

Keywords: Investigation; Suspects; Children; Crime; Drugs.

\section{Introduction}

Indonesia as a rule of law is stated in Article 1 paragraph (3) of the 1945 Constitution of the Republic of Indonesia that: "The State of Indonesia is a state of law". One of the characteristics of a rule of law state is that it requires government participation in protecting human rights (hereinafter referred to as HAM). The natural rights of the people that must be protected by the state are inseparable from humans from the state of nature, namely life, liberty and estate. The state gets the legitimacy of its power from the people only because of the belief that the state will realize the human rights of its people. ${ }^{1}$ One of the human rights guaranteed by the state is the right to health.

In order to improve the health status of Indonesia's human resources in the context of realizing the welfare of the people, it is necessary to increase efforts in the field of treatment and health services, among others by making efforts to provide for certain types of narcotics which are urgently needed as drugs and to prevent and eradicate

\footnotetext{
${ }^{1}$ Kurnia, Titon Slamet. (2007). Hak Atas Derajat Kesehatan Optimal Sebagai HAM di Indonesia. Bandung: Alumni. p. 25.
} 
the dangers of abuse and illicit narcotics trafficking. In addition, narcotics are drugs or substances that are useful in the field of medicine or health services and the development of science and on the other hand can also cause dependency which is very detrimental if misused or used without strict and thorough control and supervision. $^{2}$

Currently the abuse of narcotics by children is a concern of many people and is constantly being discussed and published. In fact, the problem of narcotics abuse has become a concern of various groups. Almost all of them reminded and wanted the Indonesian people, especially children, to never try and consume narcotics. The fact that is sanctioned almost every day through both printed and electronic media, it turns out that the circulation of narcotics has spread everywhere regardless of age, especially among the nation's future generations in the future development of the State.

The police in carrying out their duties as law enforcers, not only must comply with the applicable law as an external aspect, but they are also equipped with police ethics as an aspect of the police. Police ethics are norms regarding police behavior to serve as guidelines in realizing the implementation of good duties for law enforcement, public order and public security. ${ }^{3}$ Police who are unethical and do not have integrity in their duties have become parasites of justice that have created the Criminal Justice System (SPP) as a vicious circle of the judicial mafia. The public is reluctant to deal with the police/police agencies because they have become machines of terror and horror. This is a clear example that SPP is criminogenic. ${ }^{4}$ In fact, the use of violence by the police in criminal law enforcement is still emerging. Indriyanto Seno Adji argued that such behavior was entrenched, especially in investigations to get the defendant's confession. ${ }^{5}$

The rampant abuse of narcotics by children that occurs is caused by various factors, one of which is the high rate of illicit narcotics trafficking. On the one hand, a child who commits a crime of narcotics abuse is a criminal offender who must be punished based on the provisions of the regulations in Indonesia. On the other hand, children are victims, considering that children are still at an immature age who cannot distinguish between good or bad and right or wrong, coupled with various factors that easily influence children to commit these crimes, so they need legal protection. .

Drug abuse is still a chronic problem that afflicts Indonesia, cases of methamphetamine distribution and the many arrests of international drug dealers in recent years are proof that Indonesia is in a state of drug emergency. The Indonesian government puts forward the role of the Police and the National Narcotics Agency (BNN) in order to prevent and eradicate drug trafficking in Indonesia. The efforts to prevent and eradicate drugs are carried out in three stages, namely first, Preemptive, namely prevention efforts carried out early. Second, prevention, namely efforts that

\footnotetext{
2 Bakhri, Syaiful. (2012). Tindak Pidana Narkotika dan Psikotropika: Suatu Pendekatan Melalui Kebijakan Hukum Pidana. Jakarta: Gamarta Pub. p. 15

${ }^{3}$ Kunarto. (1997). Etika Kepolisian. Jakarta: Cipta Manunggal. p. 97

${ }^{4}$ Muladi. (1999). Kapita Selekta Sistem Peradilan Pidana. Semarang: BP. p. 24-26

${ }^{5}$ Adji, Indriyanto Seno. (1998). Penyiksaan dan HAM dalam Perspektif KUHAP. Jakarta: Pustaka Sinar Harapan. p. 4.
} 
are strategic in nature and constitute medium and long-term action plans, but must be viewed as urgent actions to be implemented immediately. Third, repressive, is an effort to overcome law enforcement actions starting from being carried out by intelligence. $^{6}$

The objectives of this research are: To identify and analyze the process of investigating child suspects in drug crimes. To find out and analyze the obstacles in the process of investigating child suspects in drug crimes and their solutions.

\section{Research methods}

The approach method used in this study is a sociological juridical approach. Sociological juridical approach is to identify and conceptualize law as real and functional social institutions in real life systems. ${ }^{7}$ This research is descriptive in nature, namely research that aims to accurately describe a particular individual, condition, symptom or group, or to determine whether there is a relationship between a symptom and other symptoms in society. ${ }^{8}$

\section{Result and Discussion}

\subsection{The Process of Investigating Child Suspects in Drug Crime}

Recently, narcotics and illegal drug crimes have been transnational in nature carried out with a high modus operandi and sophisticated technology, law enforcement officials are expected to be able to prevent and overcome these crimes in order to improve morality and the quality of human resources in Indonesia, especially for the next generation. ${ }^{9}$ Drug abuse is closely related to illicit traffic as part of the world of international crime. The illicit trafficking mafia supplies drugs so that people become dependent so the amount of supply increases. The relationship between the dealer and the victim makes it difficult for the victim to get away from the dealer, and it is not uncommon for victims to be involved in illicit trafficking due to their increased need and dependence on drugs. ${ }^{10}$

The illicit trafficking of narcotics is a very dangerous threat to the survival of the younger generation. The younger generation is the target of the illicit trafficking of narcotics targeting young people who are still psychologically unstable, making them easy to be influenced to use narcotics. The younger generation is very prone to be the strategic target of the narcotics trafficking mafia. ${ }^{11}$ Teenagers are a group that is

\footnotetext{
${ }^{6}$ Bayu Puji Hariyanto, Prevention and Eradication of Drug Trafficking in Indonesia, Jurnal Daulat Hukum, Vol 1, No 1 (2018)

${ }^{7}$ Soekanto, Soerjono. (1986). Pengantar Penelitian Hukum. Jakarta: Universitas Indonesia Press. p. 51

8 Amiruddin and Zainal Asikin. (2003). Pengantar Metode Penelitian Hukum. Jakarta: Raja Grafindo Persada. p. 24.

9 Bambang Hariyono, 2009. Policy on the Formulation of Criminal Law Against Drug Offenders in Indonesia. Law Research, Diponegoro University, Semarang. p. 23

10 Martono, Lydia Harlina and Satya Joewana. (2006). Membantu Pemulihan Pecandu Narkoba dan Keluarganya. Jakarta: Balai Pustaka. p. 1

${ }^{11}$ Martono, Herlina and Satya Joewana. (2008). Belajar Hidup Bertanggungjawab, Menangkal Narkotika dan Kekerasan. Jakarta: Balai Pustaka. p. 26.
} 
vulnerable to narcotics abuse because of their tendency to want to try which is driven by curiosity. ${ }^{12}$

Narcotics abuse in Indonesia tends to increase. The impact is not only detrimental to themselves but also to environmental actors. On the one hand, drug abusers are parties who need to be helped for all treatment, but on the other hand, the community and law enforcers consider the perpetrators of early crimes to be criminals who must be punished. As a legal basis in the eradication of narcotics, Act No. 35 of 2009, there are still concerns about the definition of juridical narcotics, namely related to sanctions that can be imposed by judges, especially sanctions in the form of criminal sanctions against narcotics. Rehabilitation measures. ${ }^{13}$

Law enforcement with the aim of making people obey the law. Public obedience to the law is due to three things, namely: (1) fear of committing sins; (2) fear because the power of the authorities is related to the imperative nature of the law; (3) fear because of shame to do evil. Law enforcement by means of non-penal means has goals and objectives for internalization purposes. ${ }^{14}$

Before carrying out an investigation the police must first make a ransom letter to BAPAS (Correctional Center), namely the correctional technical implementation unit that carries out the tasks and functions of community research, guidance, supervision and assistance. The task of Bapas is to provide community guidance and child alleviation. The letter stated that the police investigator had to ask for LITMAS (Community Research) from the child suspect and for a maximum of $3 \times 24$ hours.

The process of investigating child suspects in drug crime includes:

- The period of detention for children is only valid for a maximum of 7 (seven) days and can be extended by the Public Prosecutor for a maximum of 8 (eight) days.

- Child investigators are investigating child offenders.

- In carrying out an investigation, investigators are obliged to ask for consideration from the Correctional Center (BAPAS).

- Investigators are obliged to examine child suspects in a family atmosphere.

- In conducting an examination of a suspect, the investigator's child does not wear official clothes.

- The place for detention for children is separated from the place for adult detention.

- Investigators are obliged to seek diversion.

According to the author, the process of investigating child suspects in drug crime is analyzed with law enforcement theory that the objectives of the law can at least be achieved if the law in the form of abstract rules can be implemented by relying on several supporting factors.

\footnotetext{
12 Dafit Supriyanto Daris Warsito, Criminal System against Narcotics Abusers, Jurnal Daulat Hukum Vol. 1. No. March 1, 2018 ISSN: 2614-560X

${ }^{13}$ Umar Ma'ruf,Bambang Rudi Hartoko, Controversy of Criminal Sanctions Against Narcotics Abuser in Act No. 35 of 2009, Jurnal Daulat Hukum, Vol 1, No 4 (2018): December 2018

14 Sunarso, Siswantoro. (2004). Penegakan Hukum Dalam Kajian sosiologis. Jakarta: Raja Grafindo Persada. p. 142.
} 


\subsection{Obstacles in the Process of Investigating Child Suspects in the Crime of Drugs at the Cirebon City Police and the Solution}

Determination of drug abuse as a crime begins with the placement of the abuse of Narcotics and Psychotropics as crimes in the law, which is commonly referred to as criminalization. Narcotics abuse criminal acts are criminalized through legal instruments regulating Narcotics, namely Act No. 35 of 2009 concerning the Crime of Misuse Narcotics. This law expressly stipulates several acts that can be categorized as criminal acts of drug abuse. Several articles in the Criminalized Narcotics Law are used as legal provisions regarding prohibited acts and are accompanied by criminal threats for anyone who violates the prohibition. ${ }^{15}$

The obstacles to the process of investigating child suspects in the Crime of Drugs include: The length of time of research from the Correctional Institution (BAPAS). The unavailability of special investigators for children due to limited Human Resources (HR).

Efforts are made to overcome obstacles to the process of investigating child suspects in drug crimes, namely: Increase the ability of investigators to carry out investigations so that they are able to resolve cases during the period the child is detained in accordance with the rules, namely 7 (days) of work and can extend detention to 8 (eight) working days . Increase the working relationship with BAPAS so that research and research results on children can be completed immediately. So that the results of the research can be completed immediately before the investigator hands over the child and evidence to the Public Prosecutor (JPU).

According to the author, the obstacles to the process of investigating child suspects in drug crimes and the solution are analyzed by the theory of legal protection that protects the dignity and dignity, as well as the recognition of human rights owned by legal subjects based on legal provisions from abuse or as a collection of rules or rules that will protect one thing from another.

\section{Closing}

The process of investigating child suspects in drug crime includes: The period of detention of children is only valid for a maximum of 7 (seven) days and can be extended by the public prosecutor for a maximum of 8 (eight) days. Child investigators are investigating child offenders. In carrying out an investigation, investigators are obliged to ask for consideration from the Correctional Center (BAPAS). And the obstacles to the process of investigating child suspects in the Crime of Drugs include: The length of time of research from the Correctional Institution (BAPAS). The unavailability of special investigators for children due to limited Human Resources (HR). Efforts are made to overcome obstacles to the process of investigating child suspects in drug crimes, namely: Increase the ability of investigators to carry out investigations so that they are able to resolve cases during the period the child is

\footnotetext{
${ }^{15}$ Hera Saputra, Munsyarif Abdul Chalim, Implementation of the Criminal System for Drug Abuse Offenders (Case Study at Polda Central Java), Jurnal Daulat Hukum Vol. 1. No. March 1, 2018 ISSN: 2614$560 \mathrm{X}$
} 
detained in accordance with the rules, namely 7 (days) of work and can extend detention to 8 (eight) working days. Increase the working relationship with BAPAS so that research and research results on children can be completed immediately.

Children who commit narcotics abuse crimes must continue to receive legal protection in the judicial process in the best interest of the child and must involve cooperation between law enforcement officials, government, social institutions, schools and especially parents. And the legal protection for children who are perpetrators of drug crimes should not use detention or punishment. Prison sentences cannot guarantee that a child who is admitted to a juvenile prison will become good. The efforts that need to be put forward by the Police to children are advice and appeal and involve the participation of parents and the community, prevention of narcotics crimes involving children is more appropriate when seeing children as individuals who do not have physical and mental skills.

\section{References}

\section{Journals}

[1] Bambang Hariyono, 2009. Policy on the Formulation of Criminal Law Against Drug Offenders in Indonesia. Law Research, Diponegoro University, Semarang

[2] Bayu Puji Hariyanto, Prevention and Eradication of Drug Trafficking in Indonesia, Jurnal Daulat Hukum, Vol 1, No 1 (2018)

[3] Dafit Supriyanto Daris Warsito, Criminal System against Narcotics Abusers, Jurnal Daulat Hukum Vol. 1. No. 1 March 2018 ISSN: 2614-560X

[4] Hera Saputra, Munsyarif Abdul Chalim, Implementation of the Criminal System for Drug Abuse Offenders (Case Study at Polda Central Java) Jurnal Daulat Hukum Vol. 1. No. March 1, 2018 ISSN: 2614-560X

[5] Umar Ma'ruf, Bambang Rudi Hartoko, Controversy of Criminal Sanctions Against Narcotics Abuser in Act No. 35 of 2009, Jurnal Daulat Hukum Vol 1, No 4 (2018): December 2018

\section{Books}

[1] Adji, Indriyanto Seno. (1998). Penyiksaan dan HAM dalam Perspektif KUHAP. Jakarta: Pustaka Sinar Harapan

[2] Amiruddin and Zainal Asikin. (2003). Pengantar Metode Penelitian Hukum. Jakarta: Raja Grafindo Persada

[3] Bakhri, Syaiful. (2012). Tindak Pidana Narkotika dan Psikotropika: Suatu Pendekatan Melalui Kebijakan Hukum Pidana. Jakarta: Gamarta Pub.

[4] Kunarto. (1997). Etika Kepolisian. Jakarta: Cipta Manunggal

[5] Kurnia, Titon Slamet. (2007). Hak Atas Derajat Kesehatan Optimal Sebagai HAM di Indonesia. Bandung: Alumni

[6] Martono, Herlina and Satya Joewana. (2008). Belajar Hidup Bertanggungjawab, Menangkal Narkotika dan Kekerasan. Jakarta: Balai Pustaka

[7] Martono, Lydia Harlina and Satya Joewana. (2006). Membantu Pemulihan Pecandu Narkoba dan Keluarganya. Jakarta: Balai Pustaka

[8] Muladi. (1999). Kapita Selekta Sistem Peradilan Pidana. Semarang: BP Undip 
[9] Soekanto, Soerjono. (1986). Pengantar Penelitian Hukum. Jakarta: Universitas Indonesia Press

[10] Sunarso, Siswantoro. (2004). Penegakan Hukum Dalam Kajian sosiologis. Jakarta: Raja Grafindo Persada 